BMC

Veterinary Research

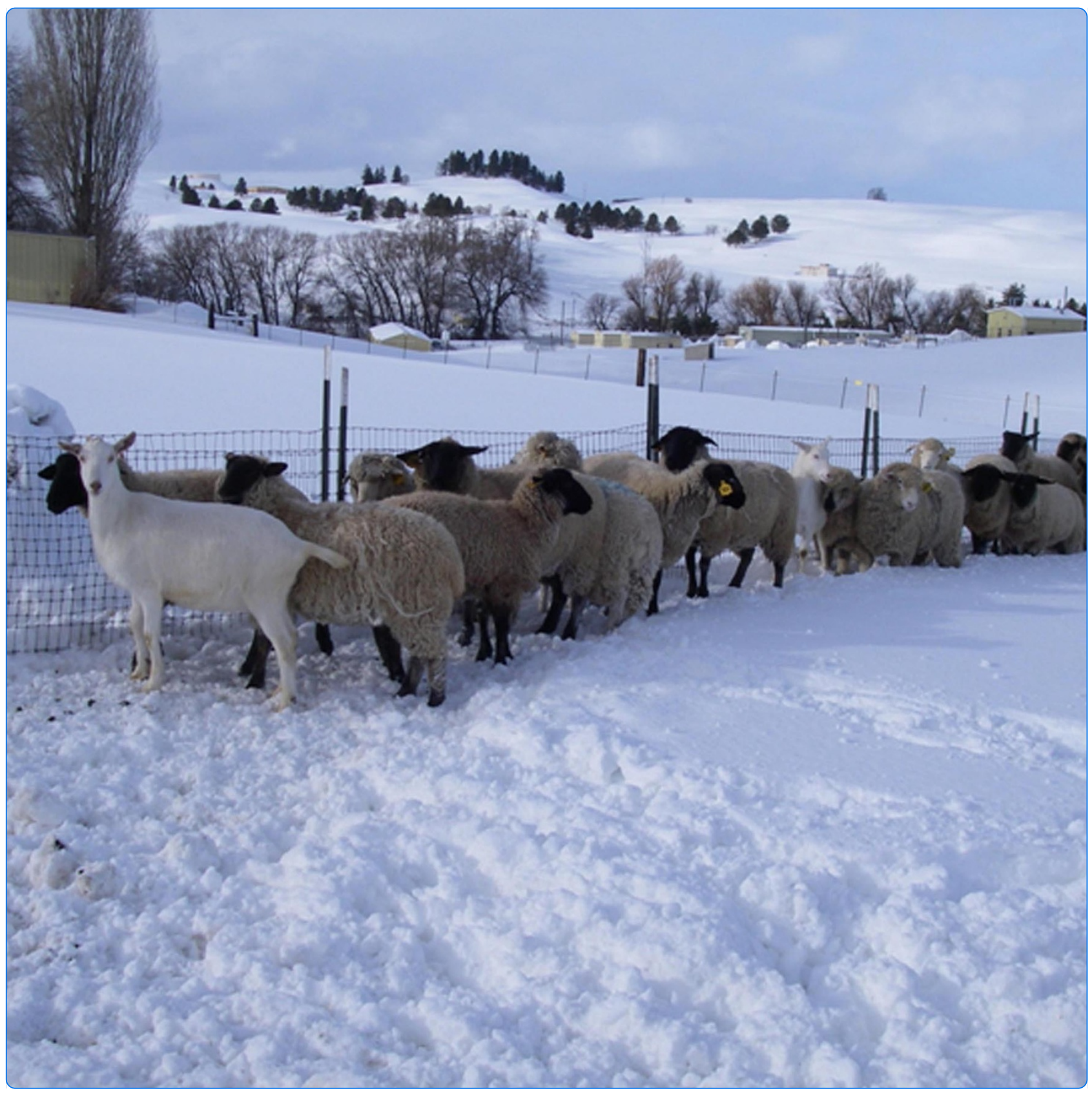

\title{
Transmissibility of caprine scrapie in ovine transgenic mice
}

O'Rourke et al. 


\title{
Transmissibility of caprine scrapie in ovine transgenic mice
}

\author{
Katherine I O'Rourke ${ }^{1 *}$, David A Schneider ${ }^{1}$, Terry R Spraker ${ }^{2}$, Rohana P Dassanayake ${ }^{3}$, Margaret A Highland ${ }^{3}$, \\ Dongyue Zhuang ${ }^{1}$ and Thomas $C$ Truscott $^{1}$
}

\begin{abstract}
Background: The United States control program for classical ovine scrapie is based in part on the finding that infection is typically spread through exposure to shed placentas from infected ewes. Transmission from goats to sheep is less well described. A suitable rodent model for examining the effect of caprine scrapie isolates in the ovine host will be useful in the ovine scrapie eradication effort. In this study, we describe the incubation time, brain lesion profile, glycoform pattern and $\operatorname{PrP}^{\mathrm{Sc}}$ distribution patterns in a well characterized transgenic mouse line (Tg338) expressing the ovine VRQ prion allele, following inoculation with brain from scrapie infected goats.
\end{abstract}

Results: First passage incubation times of caprine tissue in Tg338 ovinized mice varied widely but second passage intervals were shorter and consistent. Vacuolation profiles, glycoform patterns and paraffin-embedded tissue blots from terminally ill second passage mice derived from sheep or goat inocula were similar. Proteinase K digestion products of murine tissue were slightly smaller than the original ruminant inocula, a finding consistent with passage of several ovine strains in previous reports.

Conclusions: These findings demonstrate that Tg338 mice propagate prions of caprine origin and provide a suitable baseline for examination of samples identified in the expanded US caprine scrapie surveillance program.

Keywords: Prion, Mouse, Transgenic, Caprine

\section{Background}

Ovine and caprine scrapie are transmissible spongiform encephalopathies (TSEs) of small ruminant livestock. TSEs are also reported in domestic cattle and exotic zoo-raised bovids (bovine spongiform encephalopathy or BSE) and in farm-raised and free-ranging cervids (chronic wasting disease or CWD of deer, elk and moose). Human TSEs include a varied group of familial, sporadic, iatrogenic and infectious disorders. Human variant Creutzfeldt Jakob disease (vCJD) is a novel infectious TSE apparently originating from exposure to infectious bovine tissues [1,2] and transmitted at low rates through blood transfusion [3]. Although scrapie has not demonstrated zoonotic potential, the introduction of vCJD through exposure to domestic animal food products has led to a call for global eradication of all animal TSEs.

\footnotetext{
* Correspondence: korourke@vetmed.wsu.edu

${ }^{1}$ United States Department of Agriculture, Agricultural Research Service, Pullman, WA 99164, USA

Full list of author information is available at the end of the article
}

TSEs are characterized by accumulation of a relatively protease resistant isoform $\left(\operatorname{PrP}^{\mathrm{Sc}}\right)$ of the normal cellular prion protein $\left(\operatorname{PrP}^{c}\right)$, encoded by the PRNP gene [4]. The transmissible agent, referred to as a prion, is uniquely proteinaceous [5] and composed largely of $\operatorname{PrP}^{\mathrm{Sc}}$. In all TSEs, prions and $\operatorname{PrP}^{\mathrm{Sc}}$ accumulate in the central nervous system but significant accumulation also occurs in the lymphoid tissue and placenta [6,7] of sheep and goats with classical scrapie. Classical ovine scrapie is apparently transmitted by oral or mucosal exposure to prions shed in the placenta, blood and/or milk of infected postparturient ewes [8]. Susceptibility to infection with the classical ovine scrapie agent is associated with the amino acid sequence of the host $\operatorname{PrP}^{\mathrm{c}}$ [9]. Selection for relatively resistant breeding stock has the potential of accelerating eradication of ovine scrapie from domestic flocks.

Caprine scrapie may originate from exposure to infected sheep or infected goats. Classical ovine scrapie is readily transmitted from sheep to domestic goats by experimental oral challenge with placental tissue [8].

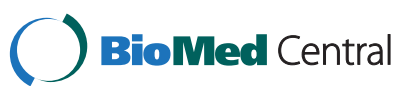


The practice of co-housing sheep and goats during parturition and the use of milk from goats for feeding orphaned lambs raise the question of whether caprine scrapie is transmissible to sheep under field conditions and if so, whether there are strains of caprine scrapie that result in novel diagnostic or transmission patterns when passaged in sheep. Large animal experiments to address these issues in the natural host are expensive and time consuming, with incubation time measured in years. The introduction of transgenic mice in which the murine PRNP gene is replaced by the PRNP gene of the species of interest has provided an alternative means for estimating interspecies transmission potential. The purpose of this study was to examine the feasibility of using the well characterized ovinized mouse strain Tg338 as a surrogate for sheep as bioassay recipients for detection of caprine prions.

\section{Results}

\section{Donor animals}

Brain tissue was collected from three domestic goats (case numbers 3538, 3558 and 30-75) and one reference domestic sheep (case number 3178) with naturallyacquired classical scrapie. All four animals had been identified as scrapie suspect animals based on antemortem detection of $\mathrm{PrP}^{\mathrm{Sc}}$ in rectal mucosal associated lymphoid tissue using immunohistochemistry. Scrapie was diagnosed by postmortem detection of $\mathrm{PrP}^{\mathrm{Sc}}$ in the medulla at the level of the obex.

PRNP genotyping was performed on the 4 donor samples. The reference sheep 3178 was homozygous for the wild type ovine allele, encoding alanine at codon 136, arginine at codon 154, and glutamine at codon 171 (ARQ/ ARQ). This genotype is identified in more than $90 \%$ of the scrapie cases diagnosed in the US [10] and Canada [11]. The caprine PRNP gene is highly polymorphic $[12,13]$ and there is no standard nomenclature for naming alleles. Polymorphisms have been identified on two haplotypes, differing at codon 240 (encoding proline P or serine S). Goat 3538 was homozygous for the wild type allele encoding $240 \mathrm{P}$ with no other polymorphisms on either strand. Goat 30-75 was heterozygous for 2 alleles on the 240P backbone; the wild type allele encoding glycine at codon 127 and an alternative allele encoding serine at that site. Goat 3558 was heterozygous for 2 alleles on the 240P backbone; the wild type allele encoding isoleucine at codon 142 and an alternative allele encoding methionine at that site.

Brain homogenates were assessed for relative $\operatorname{PrP}^{\mathrm{Sc}}$ levels using serial endpoint dilutions in western blot and ELISA (Figure 1, panels A-D). ELISA testing using a commercial kit was performed on serial two-fold dilutions of brain homogenate; the coefficient of variation (CV) for the 24 samples (6 dilutions per homogenate for each of 3 goats and 1 sheep) ranged from 0 to 0.19 , with 20 of the 24 samples having CV of less than or equal to 0.1 (data not shown). The last serial dilution resulting in a detectable signal by either ELISA or western blot analysis varied from 23 (for goat 3558) to 186 (for goat 3538 and sheep 3178) $\mu \mathrm{g}$ starting wet weight tissue. Inoculations were performed using a standard brain homogenate inoculum equivalent to $2 \mathrm{mg}$ starting wet weight containing 71-99 $\mathrm{mg}$ total protein (data not shown).

\section{Survival curves in bioassay mice}

Shown in Figure 2 are the first (P1) and second (P2) passage survival curves for Tg338 mice inoculated by the intracerebral route with scrapie isolates derived either from the three naturally infected goats (3538, $3558,30-75)$ or a naturally infected reference sheep (3178). Median survival times with 95\% confidence intervals are reported for all isolates in Table 1. P1 survival curves were relatively prolonged in duration and variable (median survival time: range, 166-253 dpi), with limited overlaps between curves produced by the different isolates. In contrast, P2 survival curves were considerably less variable and shorter in duration (median survival times: range, 130-137 dpi). Per isolate, the median survival time was reduced upon second passage by $36-116 \mathrm{dpi}$. Since the P1 survival curve for the isolate derived from goat 3538 appeared biphasic, the P1 brain homogenate from two mice, a shorter survival time mouse (228 dpi) and a longer survival time mouse (331 dpi), were used in P2 for this caprine scrapie sample. A significant difference was not observed between these two subset P2 survival curves (data not shown; Wilcoxon Chi-square $=2.1399, \quad P=0.1453)$. Thus, these two data subsets were combined for calculation of the median survival time reported for this sample in Table 1.

\section{Western blot analysis}

Western blot analysis of brain homogenates from donor goats $(n=3)$ and sheep $(n=1)$ and bioassay recipient Tg338 mice ( $n=17$ P1, 21 P2 mice) showed the characteristic banding pattern of proteinase $\mathrm{K}$ resistant $\mathrm{PrP}^{\mathrm{Sc}}$. Representative data are shown in Figure 3. Ovine and caprine brain samples co-migrated and were detected with antibodies binding the carboxyl terminus (mAb F99/97.6.1, residues 221-224) (Figure 3A), the amino terminus (mAb P4, residues 93-99) (Figure 3B), and the central region (SAF84, residues 167-172) (data not shown). For samples derived from all Tg338 mice, the unglycosylated band migrated with an apparent molecular weight approximately 1.5$2 \mathrm{kDa}$ lower than the samples from sheep and goat donor tissues. Epitope mapping demonstrated the loss of the epitope for amino terminus mAb P4 (Figure 3B) but 

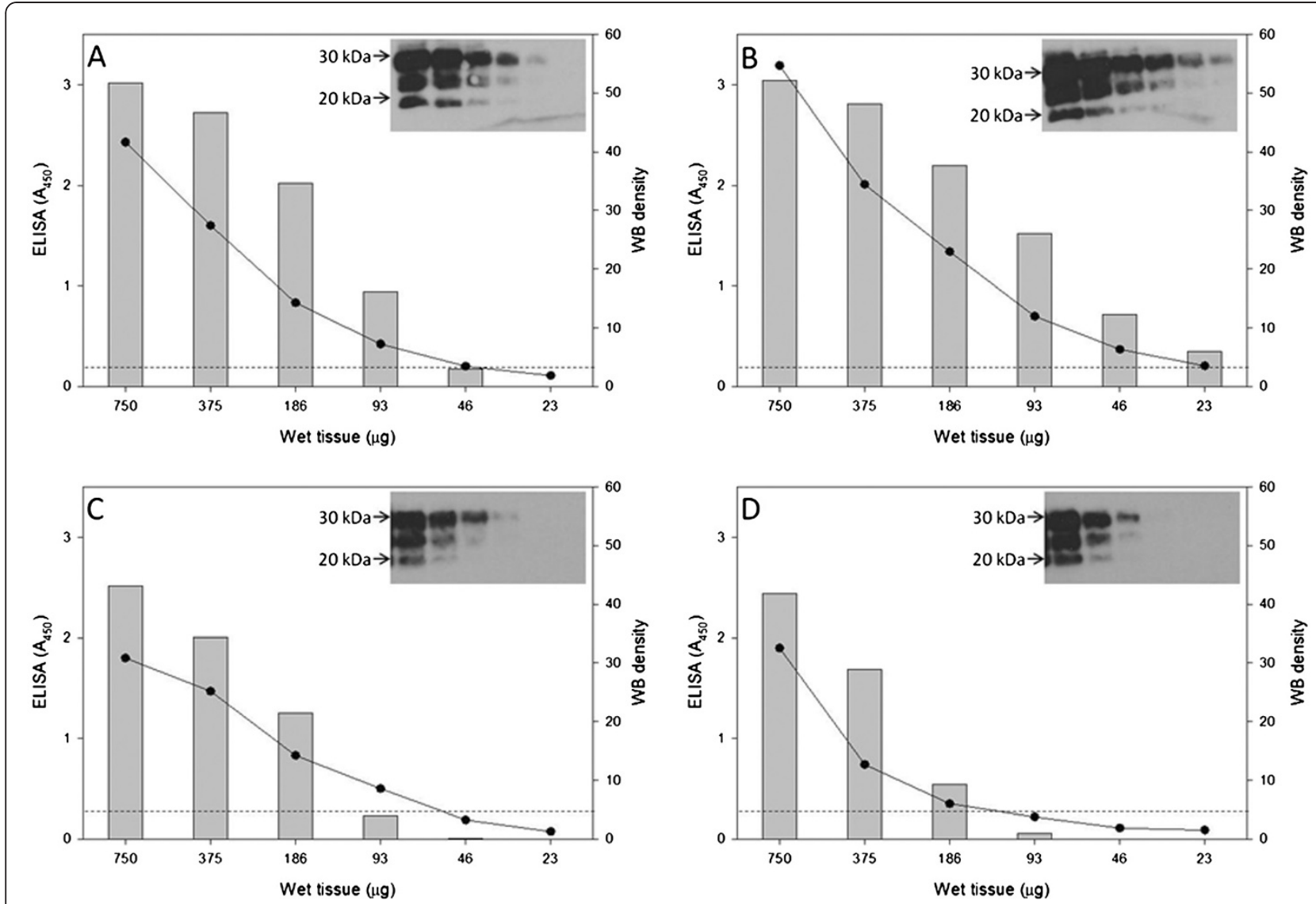

Figure 1 Relative levels of $\mathrm{PrP}^{\mathrm{Sc}}$ in brain homogenate from donor animals. Serial two-fold dilutions of brain homogenate from goat 3538 (A), 3558 (B), 30-75 (C) and reference sheep 3178 (D) were analyzed by western blot analysis and ELISA. Absorbance ( $\left.A_{450}\right)$ results from ELISA (-.-) are shown on the left y axis and density of the diglycosylated band determined from scans of western blot (vertical bars and inset image) on the right $y$ axis. Starting wet weight equivalents per ELISA well or Western blot lane are shown on the $x$ axis. Cut off limit for the ELISA (___________ ) was determined from the manufacturer's negative control sample.

conservation of the epitope for mAb F99/97.6.1 (Figure 3A). There was no evidence of a $14 \mathrm{kDa}$ carboxyl fragment when using mAb SAF84 [14].

The possibility that the apparent shift in the PK cleavage site on mouse passage was due to replication in peripheral tissues and subsequent dissemination to the brain was addressed by intraperitoneal challenge of mice with the reference sheep homogenate. Electrophoretic profiles of $\mathrm{PrP}^{\mathrm{Sc}}$ from the brain tissue of P1 (Figure 4, lane 4) or P2 (Figure 4, lane 2) mice inoculated with the reference sheep brain homogenate (Figure 4, lanes 1, 3, 5 and 7) by the IC route (Figure 4, lanes 2 and 4) were similar to those from the brain of P1 mice inoculated by the intraperitoneal (IP) route (Figure 4, lane 6), demonstrating co-migration of brain-derived $\mathrm{PrP}^{\mathrm{Sc}}$ from murine samples regardless of route of inoculation. $\operatorname{PrP}^{\mathrm{Sc}}$ bands from Tg338 spleen samples (Figure 4, lane 8) had a slightly slower migration rate than those from brain samples, ruling out peripheral amplification as a mechanism for the profile shift.

\section{Glycoform analysis}

Glycoform analysis was performed on PK-digested homogenates of P2 Tg338 brain from each of the 4 inoculum groups (1 reference sheep and 3 goats with naturally occurring scrapie). Western blots were scanned and the percent of the total density represented in each of the $3 \mathrm{PrP}^{\mathrm{Sc}}$ bands was plotted. Although identical wet weight equivalents $(300 \mu \mathrm{g})$ of each P2 mouse brain homogenate were loaded, the relative amount of $\operatorname{PrP}^{\mathrm{Sc}}$ in each sample slightly varied among mice (Additional file 1). The relative amounts of the $\operatorname{PrP}^{\mathrm{Sc}}$ bands were diglycosylated $>$ monoglycosylated $>$ unglycosylated (Figure 5 and Additional file 2). Notwithstanding minor differences in relative band densities, graphic display on a tri- 


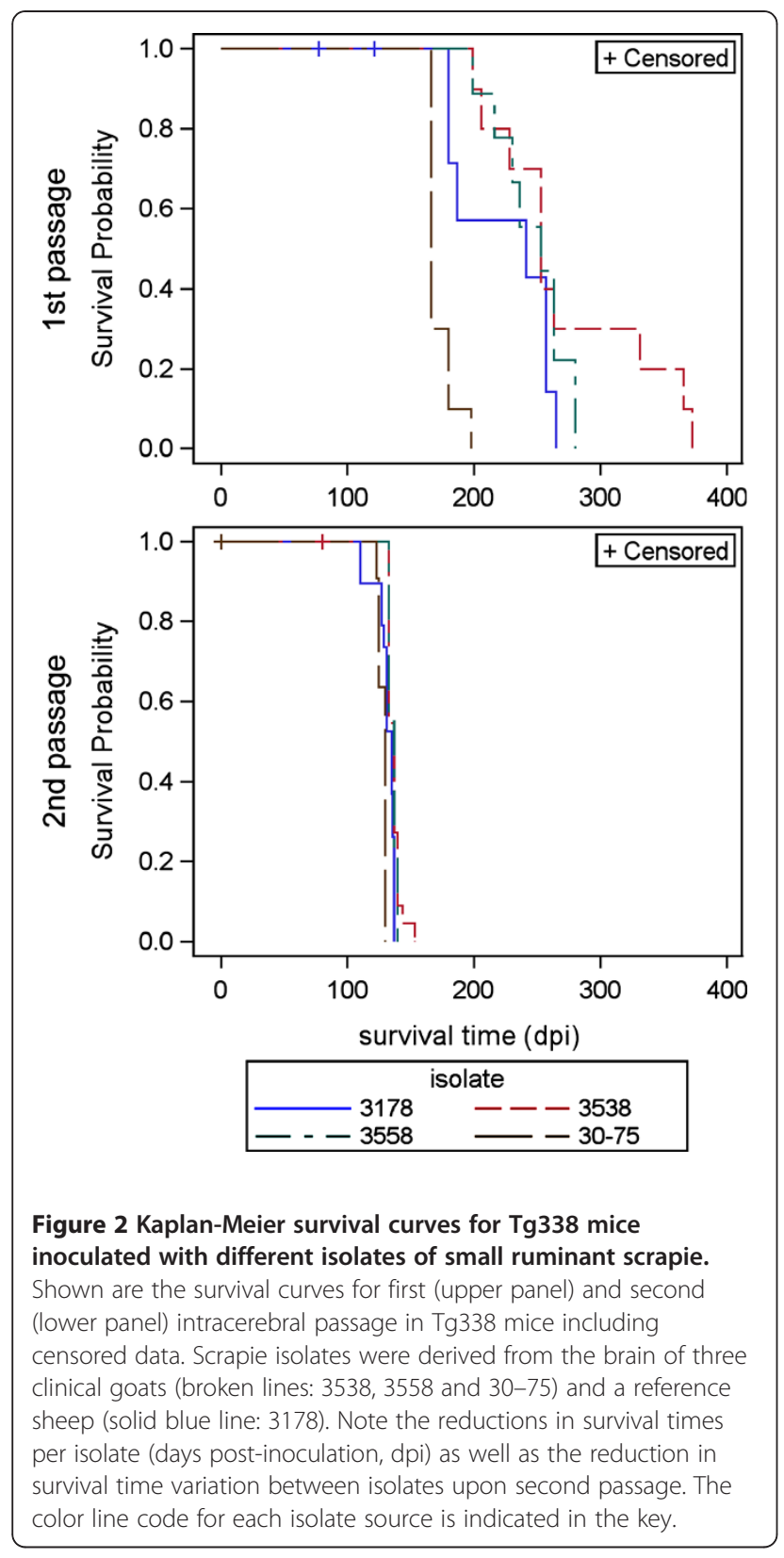

plot clearly shows clustering of all 4 four scrapie isolates (Figure 5).

\section{Histologic scoring of vacuolization by brain region of $\operatorname{Tg} 338$ mice}

Distribution and severity of vacuolization was assessed in P2 Tg338 mice from each of the 4 inoculum groups. Twelve regions (9 grey matter, 3 white matter) [15] of each second passage Tg338 mouse and non-inoculated, age-matched mice were scored for vacuolization by a pathologist (TRS) without knowledge of inoculum group. Vacuolization was not observed $($ score $=0)$ within any of the twelve brain regions of non-inoculated mice
Table 1 Inoculum groups and median survival times after serial intracerebral passage in Tg338 mice

\begin{tabular}{|c|c|c|c|c|c|}
\hline \multicolumn{2}{|c|}{ Inoculum groups } & \multirow[t]{2}{*}{ Passage } & \multirow{2}{*}{$\begin{array}{l}\text { Recipients } \\
\text { tested }^{1}\end{array}$} & \multirow{2}{*}{$\begin{array}{l}\text { Median } \\
\text { survival time } \\
\text { (dpi) }\end{array}$} & \multirow{2}{*}{$\begin{array}{l}95 \% \\
\text { LCL-UCL }^{2} \\
\text { (dpi) }\end{array}$} \\
\hline $\begin{array}{l}\text { Donor } \\
\text { species }\end{array}$ & $\begin{array}{l}\text { Donor } \\
\text { case number }\end{array}$ & & & & \\
\hline \multirow[t]{3}{*}{ goat } & $30-75$ & P1 & 10,0 & 166.0 & $166.0-180.0$ \\
\hline & 3538 & & 10,0 & 253.0 & 199.0-331.0 \\
\hline & 3558 & & 9,0 & 253.0 & $199.0-280.0$ \\
\hline sheep & 3178 & & 7,3 & 241.0 & $180.0-257.0$ \\
\hline \multirow[t]{3}{*}{ goat } & $30-75$ & P2 & 11,3 & 130.0 & $125.0-130.0$ \\
\hline & 3538 & & 22,2 & 137.0 & $133.0-137.0$ \\
\hline & 3558 & & 9,0 & 137.0 & 133.0-139.0 \\
\hline sheep & 3178 & & 19,0 & 135.0 & $129.0-136.0$ \\
\hline
\end{tabular}

${ }^{1}$ Kaplan-Meier product-limit estimation of survival functions for $n$ non-censored and $c$ censored recipients per isolate.

${ }^{2} 95 \%$ lower and upper confidence limits (UCL, LCL) were determined using the $\log (-\log )$ transform.

except for within G2 where a score of "1" was recorded for one mouse; the mean ( \pm standard error) score for region G2 in non-inoculated mice was thus $0.125 \pm 0.354$ ( $\mathrm{n}=8$ mice), which is not significantly different than a score of 0 .

Mean vacuolization scores and variation for $\mathrm{P} 2 \mathrm{Tg} 338$ mice are shown in Figure 6. The mean vacuolization scores in all inoculum groups were significantly greater than 0 in brain regions G1, G4, G5, G7, and W2 and W3, but were not significantly different from zero in

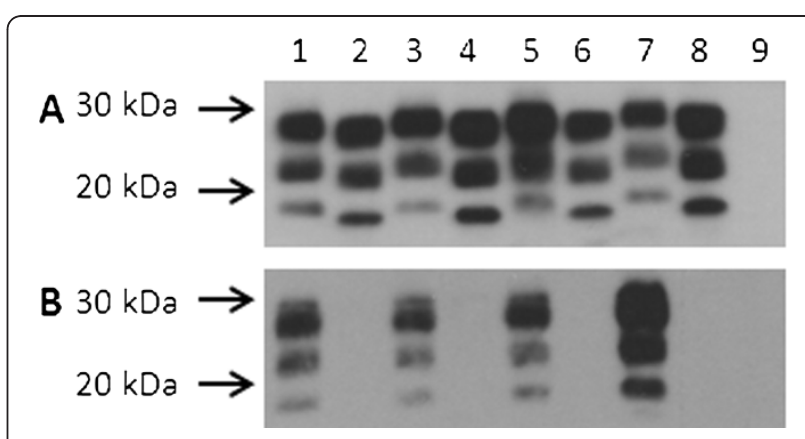

Figure 3 Western blot analysis of brain from small ruminants and P2 Tg338 mice bioassay recipients. Western blot analysis of brain from goat 3538 (lane 1, $150 \mu \mathrm{g}$ starting wet weight brain ), goat 3558 (lane 3, $250 \mu \mathrm{g}$ ), goat 30-75 (lane 5, $250 \mu \mathrm{g}$ ) and sheep 3178 (lane $7,350 \mu \mathrm{g}$ ), and brain from P2 mice from each of those 4 inoculum groups (lanes 2, 4, 6 and 8, respectively, loaded with 60-100 $\mu \mathrm{g}$ brain) after digestion with proteinase $\mathrm{K}(50 \mu \mathrm{g} / \mathrm{ml}$ final concentration for goats and sheep, $100 \mu \mathrm{g} / \mathrm{ml}$ final concentration for mice) and detection with mAb F99/97.6.1, binding a carboxyl epitope (A) or mAb P4, binding an amino terminal epitope (B). Lane 9 contains brain $(300 \mu \mathrm{g})$ from an age-matched uninoculated Tg338 mouse, homogenized and treated with proteinase $\mathrm{K}$ as described for tissue from P1 and P2 mice. Molecular mass markers are shown on the left. 


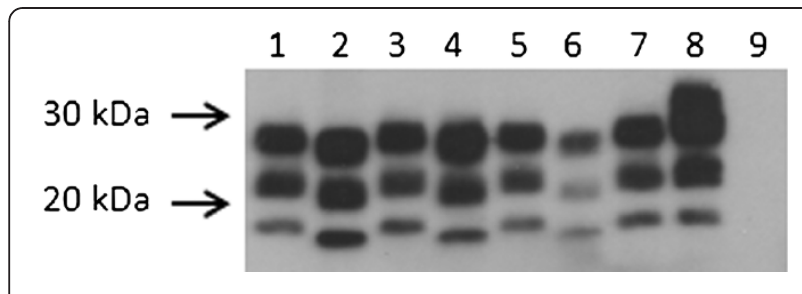

Figure 4 Co-migration of brain homogenates from Tg338 mice inoculated by the intracerebral route or the intraperitoneal route. Brain homogenate from sheep 3178 (lanes 1, 3, 5 and 7, $350 \mu \mathrm{g}$ starting wet weight per lane) and Tg338 mice (100 $\mu \mathrm{g}$ starting wet weight per lane) inoculated by the intracerebral route and assayed at passage 2 (lane 2) or passage 1 (lane 4). The same homogenate was inoculated intraperitoneally in Tg338 mice; first passage brain (lane 6) and spleen (lane 8) homogenates were assayed. Lane 9, brain homogenate (200 $\mu \mathrm{g}$ starting wet weight) from uninoculated Tg338 mouse. All tissues were digested with proteinase $\mathrm{K}(100 \mathrm{\mu g} / \mathrm{ml}$ final concentration for murine tissues and $50 \mathrm{\mu g} / \mathrm{ml}$ final concentration for ovine tissues). Filter was probed with mAb F99/97.6.1. Molecular mass markers are shown on the left.

regions G2, G6, G8, G9 and W1. Mean vacuolization scores in region G3 were the most variable: the mean vacuolization score was significantly increased for groups derived from sheep $3178(\mathrm{n}=10)$ and goat 3538 $(\mathrm{n}=11)$ but not for goats $3558(\mathrm{n}=4)$ and $30-75(\mathrm{n}=5)$.

\section{PET blots}

Paraffin embedded tissue (PET) blot analysis was performed on brain sections from one mouse in each P1 inoculum group and 4 to 9 mice in each of the P2 groups.

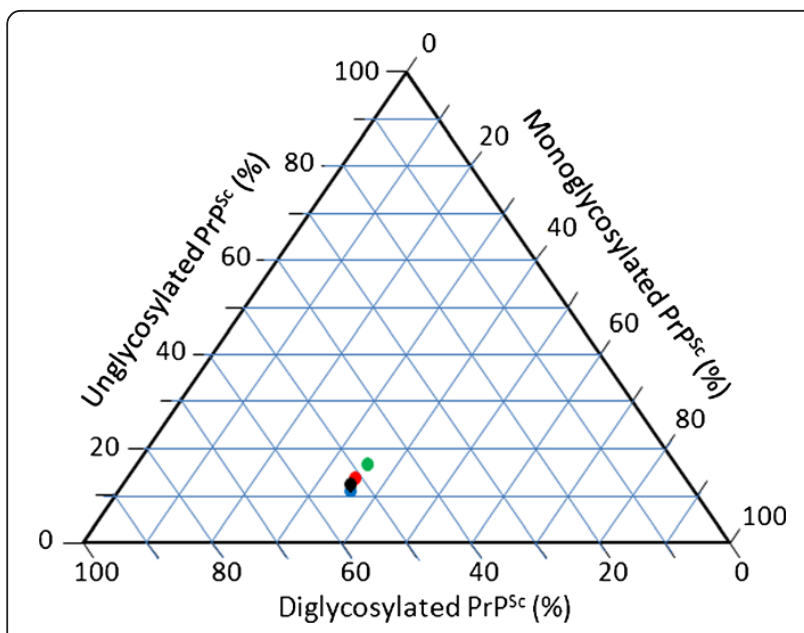

Figure 5 Glycoform analysis of $\mathrm{PrP}^{\mathrm{Sc}}$ in $\mathrm{Tg} 338$ mice inoculated with different isolates of small ruminant scrapie. Relative densities of unglycosylated, monoglycosylated and diglycosylated forms of $\mathrm{PrP}^{\mathrm{Sc}}$ bands were obtained for each P2 mouse brain using an image analyzer. Green circle - inoculum group 3558; red circle inoculum group 3538; black circle - inoculum group 30-75; blue circle - inoculum group 3178.
Representative data are shown in Figure 7. No labeling was detected in brains from negative controls (Figure 7C) or in samples labeled with an isotype control antibody (data not shown). PK-resistant $\operatorname{PrP}$ was visible at all 4 anatomic levels in sections from infected mice, with dense labeling in the striatum, ventral pallidum, claustrum, insular cortex, paraterminal body and cingulated cortex at level 1, the thalamus and hypothalamus at level 2, the superior colliculus and midbrain at level 3 and deep cerebellar nuclei and medulla at level 4 . There was no evidence of species-specific discriminatory labeling and no significant variation within the 3 caprine scrapie groups.

\section{Discussion}

Bioassay of tissues from scrapie infected sheep and goats demonstrated the transmissible nature of the disorder and the novel characteristics of the infectious agent well before the introduction of the prion hypothesis [16,17]. Oral and parenteral challenge demonstrated the susceptibility of goats to ovine scrapie [18-20]. Reciprocal studies examining the susceptibility of sheep to caprine scrapie are less well described. Studies in the natural ruminant host are limited by the prolonged incubation time and the expense of housing large animals in biocontainment. Transgenic mice expressing a PRNP gene from a species of interest are a suitable surrogate host for some studies of prion disease in humans, cattle, sheep and deer [15,21-27]. Considerable variation is noted among transgenic strains, however, with differences in outcome associated with route of inoculation $[28,29]$, transgene sequence of the regulatory and coding regions of PRNP [30], and transgene expression level [31]. The murine Tg338 line expresses the ovine PRNP VRQ allele under the ovine PRNP promotor with overexpression of $\operatorname{PrP}^{\mathrm{c}}$ in the central nervous system and lymphoreticular system [29], sites of $\operatorname{PrP}^{\mathrm{Sc}}$ accumulation in sheep and goats. This transgenic mouse line has been useful in characterizing atypical (Nor98) [32,33] and classical scrapie in sheep of various genotypes [34,35]. Several ovine isolates have been further characterized by serial passage to identify candidate classical scrapie strains differing in biochemical or clinical profiles in $\operatorname{Tg} 338$ mice $[36,37]$. In this study, we examined the use of $\operatorname{Tg} 338$ mice as a surrogate for characterizing caprine scrapie bioassayed in the ovine host. We examined incubation time, neuropathological phenotype, glycoform profile, and proteinase $\mathrm{K}$ cleavage pattern following primary and secondary passage of brain homogenates from three goats with naturally acquired scrapie. Brain tissue from a sheep homozygous for the PRNP ARQ allele was used as a reference ovine scrapie case.

Incubation times for all 4 inoculum groups were prolonged and variable upon primary passage to Tg338 


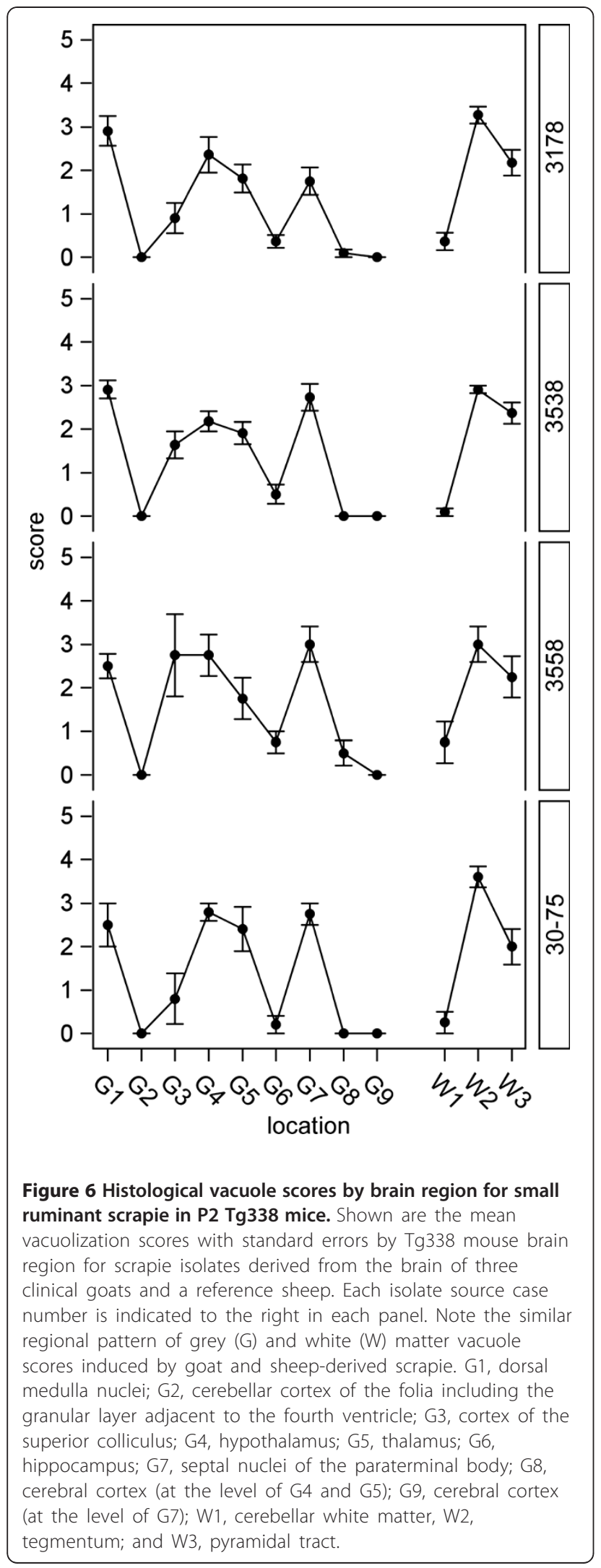

mice; mean incubation times were not related to ELISA/ Western blot titer. The sample from goat 3538 showed the widest variation in survival time on primary passage, with insidious onset at as early as 199 days and clinical signs of ataxia, weight loss and kyphosis by 206 days; survival times in some mice in this group exceeded 300 days. Mice were euthanized at $199-228$ days $(n=3$ short incubation), at 253-263 days ( $\mathrm{n}=4$ mid-range incubation), and at greater than 331 days ( $\mathrm{n}=3$ long incubation). Subpassage of samples from mice in the short (228 days) and long (331 days) incubation groups resulted in shorter incubation periods and mean survival times with no significant difference between the short and long incubation sample recipients $(137+/-2$ and $135+/-5$ respectively); likewise, there was no significant difference among the groups of P2 mice from the other inocula.

Several phenotypes have been described following passage of tissue from scrapie infected sheep to $\mathrm{Tg} 338$ mice. Notably, differences in incubation time on primary and secondary passage associated with differences in electrophoretic profiles have been described [36,38], particularly in sheep with alleles occurring on the ARQ haplotype. These cases have been reported as homozygous for alleles encoding ARQ at codons 136, 154 and 171 , and the effect of other polymorphisms (nonsynonymous changes at codon 141 or 241 for instance, on the ARQ backbone in donor sheep) has not been determined. Multiple electrophoretic patterns arising from a single ovine homogenate occur as individual or mixed profiles, even when this variation was not noted in the original ovine sample [38]. In our study, the electrophoretic profiles from all murine samples showed only a fast migrating unglycosylated band corresponding to a reduction of $\sim 1.5$ to $2 \mathrm{kDa}$ in apparent molecular mass when compared to the ruminant derived samples. The shift in PK cleavage site was confirmed by marked reduction of reactivity by $\mathrm{mAb} \mathrm{P} 4$, which recognizes an epitope at ovine residues 93-99. Western blot analysis with antibody SAF84 showed no evidence of a $14 \mathrm{kDa}$ band, ruling out a strain $\mathrm{CH} 1641$ pattern [14]. The pattern of prolonged incubation associated with reduced apparent molecular weight product in Western blot is consistent with ARQ isolates characterized by Thackray et al. [34,36], Beck et al. [38], and Tixador et al. [39]. Our observation was not based on an inherent characteristic of the $\mathrm{Tg} 338$ mouse line or our methods, as samples from mice infected with VRQ ovine tissues migrate at $\sim 21 \mathrm{kDa}$ (data not shown).

PET blots, glycoform analysis, and lesion profiles of the Tg338 samples derived from caprine brain inoculation were remarkably consistent. The marked uniformity in survival time following secondary passage and the consistent patterns in PET blot, glycoform analysis and 


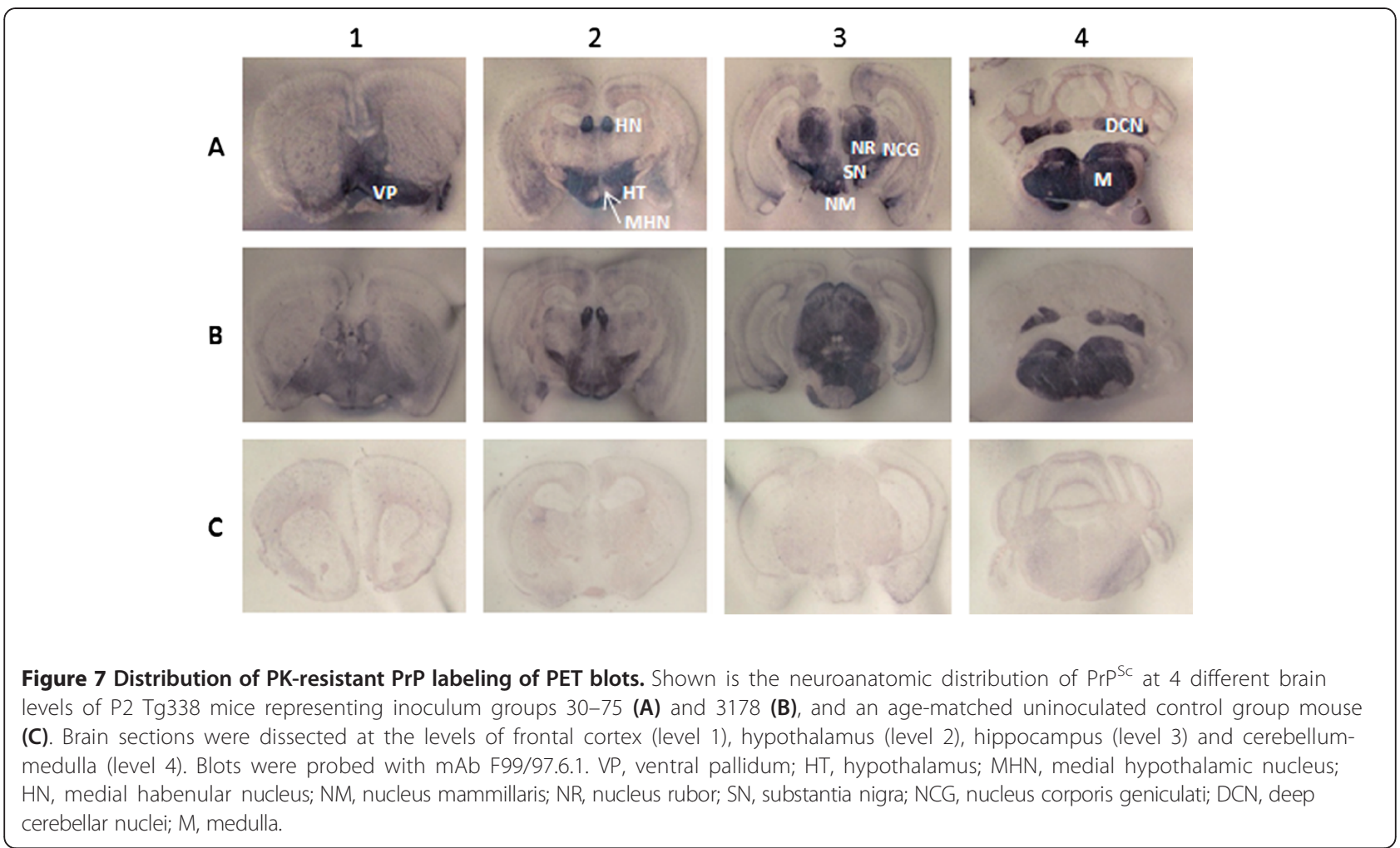

electrophoretic profile suggest that the caprine isolates, derived from separate herds, represent a single strain with characteristics of a predominant US ovine scrapie strain. This finding is not surprising; scrapie appears to have been introduced into the US in sheep and is observed almost exclusively in ARQ homozygous sheep. Subsequent spread to goats is reported only rarely and there may be a limited number of caprine scrapie strains in the population. The US will expand caprine scrapie surveillance over the next 3 years as ovine scrapie nears eradication; as additional samples from goats are identified, monitoring of caprine scrapie strains in the US using biochemical methods and bioassay in Tg338 mice should be useful in identifying any additional strains.

\section{Conclusions}

The Tg338 mouse strain expressing the VRQ allele of the ovine PRNP gene is useful in detection and analysis of ovine prions. In this study, this murine strain was found to propagate prions following intracerebral inoculation with brain homogenates from goats with naturally occurring scrapie. The electrophoretic profile and incubation time on secondary passage were similar to those observed by passage of ARQ homozygous sheep. The high attack rate and uniform findings on PET blot, glycoform analysis and lesion profile provide a suitable baseline for examination of caprine samples identified in the expanded US caprine scrapie surveillance program.

\section{Methods}

\section{Animals and PRNP genotyping}

The Washington State University and University of Washington Institutional Animal Care and Use Committees granted approval for the study before it was conducted, under agreements 3811, 3815 and 1640. Breeding pairs of transgenic $\operatorname{Tg} 338$ mice were kindly provided by Hubert Laude and held in a breeding colony at the University of Washington. The presence of the transgene was confirmed by DNA analysis of tail snips.

Scrapie infected goats and sheep were diagnosed by antemortem analysis of rectal mucosal associated lymphoid tissue [40] or post mortem analysis of brain and retropharyngeal lymph node for evidence of $\mathrm{PrP}^{\mathrm{Sc}}$ deposits detected by monoclonal antibody immunohistochemistry [41]. Donor tissue was collected from three domestic mixed breed goats (case numbers 3558, 3538, and 3075 ) and one reference sheep (case number 3178). The animals were acquired from separate flocks, although 30-75 and 3538 were born at the same facility. Postmortem confirmation was performed at the National Veterinary Services Laboratory, USDA, Ames IA, USA, using immunohistochemistry analysis of brain using monoclonal antibody (mAb) F99/97.6.1.

Diploid PRNP genotypes were determined by polymerase chain reaction amplification of the open reading frame followed by DNA sequence analysis of both strands using standard methods [12,42]. 


\section{Mouse inoculations}

Brain tissue from the three goats with naturally acquired scrapie and the reference sheep with classical ovine scrapie were prepared as $10 \%(\mathrm{w} / \mathrm{v})$ homogenates in normal saline. Relative titer of each homogenate was estimated from serial dilution and endpoint titration using a commercial enzyme linked immunosorbent assay and western blot analysis as described below. Total protein levels varied slightly among the inocula: $2 \mathrm{mg}$ starting wet weight tissue yielded 76 (goat 3538), 71 (goat 3558), 85 (goat 30-75) and 99 (sheep 3178) $\mu \mathrm{g}$ total protein as determined by BCA protein assay. Passage 1 (P1) Tg338 mice were inoculated with $20 \mu \mathrm{l}$ of $10 \%(\mathrm{w} / \mathrm{v})$ sheep or goat brain homogenate ( $2 \mathrm{mg}$ starting wet weight tissue) by the intracerebral route in the right parietal lobe. Serial passage of murine brain (passage 2, P2) was performed using $20 \mu \mathrm{l}$ of a $10 \%(\mathrm{w} / \mathrm{v})$ homogenate of brain from clinically affected P1 mice administered by the intracerebral route as above. An additional group of mice was inoculated intraperitoneally with brain homogenate from sheep 3178 using $2 \mathrm{mg}$ starting wet weight tissue in a final volume of $200 \mu \mathrm{l}$. Inoculated animals and age matched uninoculated controls were monitored daily for appearance of clinical signs suggestive of scrapie (weight loss, lethargy and kyphosis) and culled at terminal disease. Brain and spleen were collected from mice at necropsy. Samples were fixed in 10\% buffered formalin or frozen at-20C for western blot analysis.

\section{Incubation time}

Survival time following intracerebral challenge with brain homogenates from goats or sheep (P1) or mouse (P2) was recorded as days post-inoculation (dpi). Recipient animals terminated for reasons other than clinical scrapie disease were considered censored data. The survival function of each scrapie isolate was determined using the Kaplan-Meier product-limit estimation method (LIFETEST procedure, SAS for Windows version 9.2; SAS Institute Inc., Cary, NC, USA). Median survival times with $95 \%$ confidence limits were determined by the $\log (-\log )$ method.

\section{Relative PrP ${ }^{\mathrm{Sc}}$ levels in goat and sheep inoculum}

Relative amounts of $\mathrm{PrP}^{\mathrm{Sc}}$ in brain homogenates from three goats and one reference sheep with scrapie were determined by serial endpoint dilution followed by enzyme linked immunosorbent assay and Western blot analysis of paired samples. Aliquots of the 10\% homogenate of sheep or goat tissue prepared for inoculation were adjusted with 2 volumes of lysis buffer $(0.5 \%$ deoxycholic acid, 0.5\% NP-40, $10 \mathrm{mM}$ Tris- $\mathrm{HCl}, \mathrm{pH}$ 7.5) using a table top homogenizer (Fastprep, Thermo Electron Co., Waltham, MA, USA). Preliminary assays demonstrated that the use of this lysis buffer did not affect ELISA readings (data not shown) and the initial dilution in lysis buffer provided a homogeneous mixture suitable for aliquoting into paired samples for ELISA and Western blot. Additional serial two fold dilutions were prepared in lysis buffer and assayed in duplicate using a commercially available $\operatorname{PrP}^{\mathrm{Sc}}$ detection kit (ELISA) (HerdCheck Scrapie-BSE Antigen Test, IDEXX Laboratories, Westbrook, ME, USA). Mean absorbance values $\left(\mathrm{A}_{450}\right)$ were plotted against starting wet weight equivalents of brain. The cutoff value was determined using the internal standard provided in the kit.

\section{Western blot analysis}

$\mathrm{PrP}^{\mathrm{Sc}}$ was detected by Western blot assay as described previously [41-43] with minor modifications. Aliquots of the $10 \%(\mathrm{w} / \mathrm{v})$ brain homogenates from sheep, goats, or mice serially diluted in lysis buffer for ELISA (above) were assayed by Western blot. Homogenates were incubated with proteinase $\mathrm{K}(\mathrm{PK})$ at $100 \mu \mathrm{g} / \mathrm{mL}$ final concentration at $37 \mathrm{C}$ for $90 \mathrm{~min}$ for murine homogenates and $50 \mu \mathrm{g} / \mathrm{mL}$ final concentration at $37 \mathrm{C}$ for $60 \mathrm{~min}$ for ovine and caprine homogenates. For the endpoint titration of sheep and goat inocula, the starting $10 \%$ homogenate in PBS was adjusted with two volumes of lysis buffer and treated with proteinase $\mathrm{K}(\mathrm{PK})$ at $50 \mu \mathrm{g} / \mathrm{mL}$ final concentration at 37C for $60 \mathrm{~min}$. Serial two fold dilutions were prepared in lysis buffer, combined with sample loading buffer (NuPage, Invitrogen, Carlsbad, CA, USA), and loaded onto 12-well $12 \% \mathrm{Nu}$-PAGE Bis-Tris gels (Invitrogen). Starting wet weight equivalents for titration were $750 \mu \mathrm{g}$ for ovine and caprine tissues. Murine tissues for glycoform analysis were assayed at $300 \mu \mathrm{g}$ per lane. After electrophoresis, proteins were transferred onto polyvinylidene fluoride (PVDF) membranes (Millipore, Billerica, MA, USA), blocked with commercial casein blocker (Pierce, Rockford, IL, USA) and incubated with primary mAb F99/97.6.1 (3.5 $\mu \mathrm{g} / \mathrm{mL}$; O'Rourke et al., 2000), mAb P4 $(0.2 \mu \mathrm{g} / \mathrm{ml}$, R-BioPharm AG, Marshall, MI, USA) or mAb SAF84 $(0.2 \mu \mathrm{g} / \mathrm{ml}$, Cayman Chemical, Ann Arbor, MI, USA) followed by incubation with a peroxidase labeled goat anti-mouse $\operatorname{IgG}_{1}$ secondary Ab (Southern Biotech, Birmingham, AL, USA; 1:5,000, for detection of mAb F99/97.6.1) or a peroxidase labeled $\mathrm{F}(\mathrm{ab}) 2$ fraction of goat anti-mouse $\operatorname{IgG}_{2}$ (KPL, Gaithersburg, MD, USA, 1:20,000 for detection of mAb $\mathrm{P} 4$ and SAF84. Bound antibody was detected by chemiluminescence (Amersham ECL, GE healthcare, Piscataway, NJ, USA). Membranes were exposed to radiographic films (Kodak BioMax Chemiluminescence Films, Rochester, $\mathrm{NY}$ ) for exposure times of 1-10 min. Digital images of the radiographic films were obtained with an Alpha Innotec image analyzer (Alpha Innotech Corp, San Leandro, CA, USA) and saved in tiff file format. Density of the diglycosylated band was plotted against starting wet weight of tissue to estimate relative endpoints. 


\section{Glycoform analysis}

Brain tissues of 20 inoculated mice (five from each donor group) were selected for glycoform analysis and tested in three independent western blot assays. For each sample, triplicate aliquots of $50 \mu \mathrm{l}$ brain homogenate were incubated with PK $(100 \mu \mathrm{g} / \mathrm{mL}$ final concentration $)$ at $37 \mathrm{C}$ for $90 \mathrm{~min}$. Aliquots equivalent to $300 \mu \mathrm{g}$ wet brain weight equivalents were loaded into individual lanes of 12 -well $12 \%$ polyacrylamide gels and analyzed by western blot assay as described above, using $\mathrm{mAb}$ F99/97.6.1. Digital images of the radiographic films were obtained with an Alpha Innotec image analyzer and saved in tiff file format. These files were analyzed with AlphaEaseFC software Version 4.0 to identify the relative densities of unglycosylated, monoglycosylated and diglycosylated forms of $\operatorname{PrP}^{\mathrm{Sc}}$. For each group of mice, mean density of each band was plotted into Tri-plot Excel template. The tri-plot excel template was downloaded from http://www.lboro.ac.uk/research/phys-geog/tri-plot [44].

\section{Histopathology}

Formalin fixed brains were processed routinely and sectioned at $5 \mu \mathrm{m}$ for hematoxylin and eosin staining. Tissues were analyzed for vacuolation profile using standard methods as described [15]. Lesion severity was quantitated as described [45]. Briefly, scores were assigned on a scale of 0 to 5 for specific neuroanatomic areas based on the intensity of the vacuolation. Regions scored were G1, dorsal medulla nuclei; G2, cerebellar cortex of the folia including the granular layer, adjacent to the fourth ventricle; G3, cortex of the superior colliculus; G4, hypothalamus; G5, thalamus; G6, hippocampus; G7, septal nuclei of the paraterminal body; G8, cerebral cortex (at the level of G4 and G5); and G9, cerebral cortex (at the level of G7). In addition, three white matter areas were scored; W1, cerebellar white matter, W2, tegmentum, and W3, pyramidal tract. Regions were assigned 0 if vacuolation was similar to that observed in negative control mice; 1 for regions with a few unevenly scattered vacuoles, 2 for regions with a few evenly scattered vacuoles, 3 for regions with a moderate number of evenly scattered vacuoles, 4 for regions with many vacuoles, including some confluence, and 5 for regions with dense vacuolation with most of the field confluent. This evaluation was done by examination of the entire region on 20X.

\section{PET blots}

Regional distribution and intensity of $\operatorname{PrP}^{\mathrm{Sc}}$ labeling in $\mathrm{P} 2$ $\mathrm{Tg} 338$ mouse brains were evaluated in paraffin embedded tissue blots. The brain sections were dissected at the levels of frontal cortex (level 1), hypothalamus (level 2), hippocampus (level 3) and cerebellum-medulla (level 4) and probed with mAb F99/97.6.1 as described [46-48], with minor modifications [49]. Eight P2 scrapie inoculated Tg338 mice, including 2 from each inoculum group and
2 age-matched uninoculated negative control mice, were evaluated as described [48].

\section{Additional files}

\begin{abstract}
Additional file 1: Brain tissue from $20 \mathrm{Tg} 338$ passage 2 mice (five from each sheep- or goat-inoculated P1 donor) were selected for western blot assay and glycoform analysis. Three hundred $\mu \mathrm{g}$ wet brain weight equivalent volumes of each of the mouse brain were digested with proteinase $\mathrm{K}$ and loaded into SDS-PAGE gels followed by western blot assay using mAb F99/97.6.1 and chemiluminescent imaging. Films (representative film shown in Additional File 1) were used to obtain relative densities of un-, mono- and di-glycosylated forms of $\operatorname{PrP}^{\mathrm{Sc}}$ bands for glycoform analysis.
\end{abstract}

Additional file 2: Glycoform patterns of $\mathrm{PrP}^{\mathrm{Sc}}$ from 3 goats and a reference sheep with naturally occurring scrapie and from Tg338 mice from each inoculum group.

\section{Authors' contributions}

$\mathrm{KIO}$ developed the study design, contributed to design of the glycoform analysis, participated in histologic scoring, performed analysis of genotypes, and drafted the manuscript. DAS performed the survival curve analysis and the vacuole pattern analysis. TRS performed the histopathological examinations. RPD performed the glycoform analysis and assisted with PET blot analysis. DZ performed the western blots, ELISA and PET blots and provided data analysis for ELISA and Western blots. MAH analyzed the PET blot data. TCT performed the histologic preparation of all small ruminant and murine tissues. All authors participated in writing the manuscript and have read and approved the final manuscript.

\section{Acknowledgements}

The USDA Agricultural Research Service provided financial support for this study under CRIS 5348-32000-026-00D. We thank L. Fuller, D. Chandler and K. Ross for care of the animals. L. Hamburg provided management of the Tg338 colony and performed the inoculations and necropsies. D. Lesiak provided PRNP genotyping. We thank S. Madsen-Bouterse and A. L. Brassfield for review of the manuscript. Mention of trade names or commercial products in this article is solely for the purpose of providing specific information and does not imply recommendation or endorsement by the US Department of Agriculture.

\section{Author details}

${ }^{1}$ United States Department of Agriculture, Agricultural Research Service, Pullman, WA 99164, USA. ²Department of Microbiology, Immunology and Pathology, College of Veterinary Medicine and Biomedical Sciences, Colorado State University, Fort Collins, CO 80526, USA. ${ }^{3}$ Department of Veterinary Microbiology and Pathology, College of Veterinary Medicine, Washington State University, Pullman, WA 99164, USA.

Received: 13 September 2011 Accepted: 17 February 2012 Published: 2 April 2012

\section{References}

1. Will RG, Ironside JW, Zeidler M, Cousens SN, Estibeiro K, Alperovitch A, Poser S, Pocchiari M, Hofman A, Smith PG: A new variant of Creutzfeldt-Jakob disease in the UK. Lancet 1996, 347:921-925.

2. Bruce ME, Will RG, Ironside JW, McConnell I, Drummond D, Suttle A, McCardie L, Chree A, Hope J, Birkett C, et al: Transmissions to mice indicate that 'new variant' CJD is caused by the BSE agent. Nature 1997, 389:498-501.

3. Peden $A H$, Head MW, Ritchie DL, Bell JE, Ironside JW: Preclinical vCJD after blood transfusion in a PRNP codon 129 heterozygous patient. Lancet 2004, 364:527-529.

4. Oesch B, Westaway D, Walchi M, McKinley MP, Kent SBH, Aebersold R, Barry RA, Tempst P, Teplow DB, Hood LE, et al: A cellular gene encodes scrapie PrP27-30 protein. Cell 1985, 40:735-746.

5. Prusiner SB: Novel proteinaceous infectious particles cause scrapie. Science 1982, 216:136-144. 
6. Hadlow WJ, Kennedy RC, Race RE: Natural infection of Suffolk sheep with scrapie virus. J Infect Dis 1982, 146:657-664.

7. Hadlow WJ, Eklund CM, Kennedy RC, Jackson TA, Whitford HW, Boyle CC: Course of experimental scrapie virus infection in the goat. $J$ Infect Dis 1974, 129(5):559-567.

8. Pattison $\mathrm{H}$, Hoare MN, Jebbett JN, Watson WA: Spread of scrapie to sheep and goats by oral dosing with foetal membranes from scrapie-affected sheep. Vet Rec 1972, 90:465-468.

9. Hunter N: PrP genetics in sheep and the implications for scrapie and BSE. Trends Microbiol 1997, 5:331-334

10. O'Rourke Kl, Melco RP, Mickelson JR: Allelic frequencies of an ovine scrapie susceptibility gene. Anim Biotech 1996, 7(2):155-162

11. Harrington NP, O'Rourke Kl, Feng Y, Rendulich J, Difruscio C, Balachandran A: Prion genotypes of scrapie-infected Canadian sheep 1998-2008. Can J Vet Res 2010, 74(3):228-232

12. White $S$, Herrmann-Hoesing L, O'Rourke $K$, Waldron D, Rowe J, Alverson J: Prion gene (PRNP) haplotype variation in United States goat breeds (Open Access publication). Genet Sel Evol 2008, 40(5):553-561.

13. Vaccari $G$, Panagiotidis $C H$, Acin C, Peletto S, Barillet F, Acutis P, Bossers A, Langeveld J, van Keulen L, Sklaviadis T, et al: State-of-the-art review of goat TSE in the European Union, with special emphasis on PRNP genetics and epidemiology. Vet Res 2009, 40(5):48

14. Baron T, Bencsik A, Vulin J, Biacabe AG, Morignat E, Verchere J, Betemps D: A C-terminal protease-resistant prion fragment distinguishes ovine "CH1641-like" scrapie from bovine classical and L-Type BSE in ovine transgenic mice. PLoS Pathogens 2008, 4(8):e1000137.

15. Beringue V, Andreoletti O, Le Dur A, Essalmani R, Vilotte JL, Lacroux C, Reine F, Herzog L, Biacabe AG, Baron T, et al: A bovine prion acquires an epidemic bovine spongiform encephalopathy strain-like phenotype on interspecies transmission. J Neurosci 2007, 27(26):6965-6971.

16. Chandler RL: Encephalopathy in mice produced by inoculation with scrapie brain material. Lancet 1961, i:1378-1379.

17. Zlotnik I, Rennie JC: Further observations on the experimental transmission of scrapie from sheep and goats to laboratory mice. J Comp Pathol 1963, 73:150-162.

18. Brotherston JG, Renwick CC, Stamp JT, Zlotnik I, Pattison $1 \mathrm{H}$ : Spread of scrapie by contact to goats and sheep. J Comp Pathol 1968, 78:9-17.

19. Dickinson AG: Scrapie in sheep and goats. In Slow virus diseases of animals and man. Edited by Kimberlin RH. Amsterdam: North-Holland; 1976:209-241.

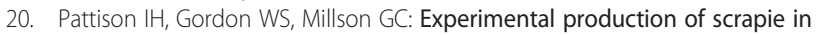
goats. J Comp Pathol 1959, 69:300-312.

21. Angers RC, Kang HE, Napier D, Browning S, Seward T, Mathiason C, Balachandran A, McKenzie D, Castilla J, Soto C, et al: Prion strain mutation determined by prion protein conformational compatibility and primary structure. Science 2010, 328(5982):1154-1158.

22. Baron T, Biacabe AG: Molecular behaviors of "CH1641-Like" sheep scrapie isolates in ovine transgenic mice (TgOvPrP4). J Virol 2007, 81(13):72307237.

23. Baron T, Crozet C, Biacabe AG, Philippe S, Verchere J, Bencsik A, Madec $J Y$, Calavas D, Samarut J: Molecular analysis of the protease-resistant prion protein in scrapie and bovine spongiform encephalopathy transmitted to ovine transgenic and wild-type mice. J Virol 2004, 78 (12):6243-6251.

24. Kong QZ, Huang SH, Zou WQ, Vanegas D, Wang ML, Wu D, Yuan J, Zheng MJ, Bai H, Deng HY, et al: Chronic wasting disease of elk: Transmissibility to humans examined by transgenic mouse models. J Neurosci 2005, 25 (35):7944-7949.

25. Meade-White K, Race B, Trifilo M, Bossers A, Favara C, LaCasse R, Miller M, Williams $E$, Oldstone $M$, Race $R$, et al: Resistance to chronic wasting disease in transgenic mice expressing a naturally occurring allelic variant of deer prion protein. J Virol 2007, 81(9):4533-4539.

26. Sandberg MK, Al-Doujaily H, Sigurdson CJ, Glatzel M, O'Malley C, Powell C, Asante EA, Linehan JM, Brandner S, Wadsworth JD, et al: Chronic wasting disease prions are not transmissible to transgenic mice overexpressing human prion protein. J Gen Virol 2010, 91(Pt 10):2651-2657.

27. Wadsworth JD, Asante EA, Collinge J: Review: contribution of transgenic models to understanding human prion disease. Neuropathol Appl Neurobiol 2010, 36(7):576-597.
28. Outram GW, Fraser H, Wilson DT: Scrapie in mice. Some effects on the brain lesion profile of ME7 agent due to genotype of donor, route of injection and genotype of recipient. J Comp Pathol 1973, 83:19-28.

29. Langevin C, Andreoletti O, Le Dur A, Laude H, Beringue V: Marked influence of the route of infection on prion strain apparent phenotype in a scrapie transgenic mouse model. Neurobiol Dis 2011, 41(1):219-225.

30. Beck KE, Cawthraw S, Saunders GC, Ellis R, Spiropoulos J: Transmission of classical scrapie to wild-type mice: the influence of the ovine PrP sequence on lesion profiles. Arch Virol 2011, 156(5):903-906.

31. Arsac JN, Betemps D, Morignat E, Feraudet C, Bencsik A, Aubert D, Grassi J, Baron T: Transmissibility of atypical scrapie in ovine transgenic mice: major effects of host prion protein expression and donor prion genotype. PLoS One 2009, 4(10):e7300.

32. Andreoletti $O$, Orge L, Benestad SL, Beringue V, Litaise C, Simon S, Le Dur A, Laude H, Simmons H, Lugan S, et al: Atypical/Nor98 scrapie infectivity in sheep peripheral tissues. PLoS Pathogens 2011, 7(2):e1001285.

33. Griffiths PC, Spiropoulos J, Lockey R, Tout AC, Jayasena D, Plater JM, Chave A, Green RB, Simonini S, Thorne L, et al: Characterization of atypical scrapie cases from Great Britain in transgenic ovine PrP mice. J Gen Virol 2010, 91(Pt 8):2132-2138.

34. Thackray AM, Hopkins L, Spiropoulos J, Bujdoso R: Molecular and transmission characteristics of primary-passaged ovine scrapie isolates in conventional and ovine PrP transgenic mice. J Virol 2008, 82(22):1119711207.

35. Vilotte JL, Soulier S, Essalmani R, Stinnakre MG, Vaiman D, Lepourry L, Da Silva JC, Besnard N, Dawson M, Buschmann A, et al: Markedly increased susceptibility to natural sheep scrapie of transgenic mice expressing ovine PrP. J Virol 2001, 75(13):5977-5984.

36. Thackray AM, Hopkins L, Lockey R, Spiropoulos J, Bujdoso R: Emergence of multiple prion strains from single isolates of ovine scrapie. J Gen Virol 2011, 92(Pt 6):1482-1491.

37. Thackray AM, Hopkins L, Lockey R, Spiropoulos J, Bujdoso: Propagation of ovine prions from "poor" transmitter scrapie isolates in ovine PrP transgenic mice. Exp Mol Pathol 2011, 92:167-174.

38. Beck KE, Sallis RE, Lockey R, Vickery CM, Beringue V, Laude H, Holder TM, Thorne $L$, Terry $L A$, Tout $A C$, et al: Use of murine bioassay to resolve ovine transmissible spongiform encephalopathy cases showing a bovine spongiform encephalopathy molecular profile. Brain Pathol 2012, 22(33):265-79.

39. Tixador P, Herzog L, Reine F, Jaumain E, Chapuis J, Le Dur A, Laude H, Beringue $V$ : The Physical Relationship between Infectivity and Prion Protein Aggregates Is Strain-Dependent. PLoS Pathogens 2010, 6(4): e1000859. doi:10.1371/journal.ppat.1000859.

40. Gonzalez L, Jeffrey M, Siso S, Martin S, Bellworthy S, Stack M, Chaplin M, Davis L, Dagleish MP, Reid HW: Diagnosis of preclinical scrapie in samples of rectal mucosa. Vet Rec 2005, 156(26):846-847.

41. O'Rourke Kl, Zhuang D, Truscott TC, Yan H, Schneider DA: Sparse PrP(Sc) accumulation in the placentas of goats with naturally acquired scrapie. BMC Vet Res 2011, 7:7.

42. Alverson J, O'Rourke Kl, Baszler TV: PrP-Sc accumulation in fetal cotyledons of scrapie-resistant lambs is influenced by fetus location in the uterus. $J$ Gen Virol 2006, 87:1035-1041.

43. Spraker TR, Balachandran A, Zhuang D, O'Rourke Kl: Variable patterns of PrP-CWD distribution in obex and cranial lymphoid tissues of Rocky Mountain elk with nonclinical chronic wasting disease. Vet Rec 2004 155:295-302.

44. Graham D, Midgley N: Graphical representation of particle shape using triangular diagrams: an Excel spreadsheet method. Earth Surface Process Landforms 2000, 25:1473-1477.

45. Frasier H, Dickinson AG: The sequential development of the brain lesion of scrapie in three strains of mice. J Comp Pathol 1968, 78:301-311.

46. Schulz-Schaeffer WJ, Fatzer R, Vandevelde M, Kretzschmar HA: Detection of $\operatorname{PrP}(\mathrm{Sc})$ in subclinical BSE with the paraffin-embedded tissue (PET) blot. Arch Virol Suppl 2000, 16:173-180.

47. Schulz-Schaeffer WJ, Tschoke S, Kranefuss N, Drose W, Hause-Reitner D, Giese A, Groschup MH, Kretzschmar HA: The paraffin-embedded tissue blot detects PrPSC early in the incubation time in prion diseases. Am J Pathol 2000, 156:51-56. 
48. Lezmi S, Bencsik A, Baron T: PET-blot analysis contributes to BSE strain recognition in C57BI/6 mice. J Histochem Cytochem 2006, 54:1087-1094.

49. Newsom DM, Liggitt HD, O'Rourke K, Zhuang D, Schneider DA, Harrington RD: Cytokine antibody array analysis in brain and periphery of scrapie-infected Tg338 mice. Comp Immunol Microbiol Infect Dis 2011, 34:387-397.

doi:10.1186/1746-6148-8-42

Cite this article as: O'Rourke et al:: Transmissibility of caprine scrapie in ovine transgenic mice. BMC Veterinary Research 2012 8:42.

\section{Submit your next manuscript to BioMed Central and take full advantage of:}

- Convenient online submission

- Thorough peer review

- No space constraints or color figure charges

- Immediate publication on acceptance

- Inclusion in PubMed, CAS, Scopus and Google Scholar

- Research which is freely available for redistribution

Submit your manuscript at www.biomedcentral.com/submit

C) Biomed Central 